\title{
RESILIENCY OF PREFABRICATED DAYCARES AND SCHOOLS: FINNISH PERSPECTIVE TO RELOCATABLE EDUCATION FACILITIES
}

\author{
Harry EDELMAN a,*, Jaakko VIHOLA a Mikko LAAK ${ }^{\text {b }}$, Petri ANNILA b \\ a Department of Civil Engineering, School of Architecture, Tampere University of Technology, Tampere, \\ Korkeakoulunkatu 5, P.O. Box 600, FIN-33101 Tampere, Finland \\ ${ }^{b}$ Architecture Information Centre Finland, Pohjoinen Makasiinikatu 6 B 1, FIN-00130 Helsinki, Finland
}

Received 23 March 2015; accepted 11 March 2016

\begin{abstract}
The industrialised production of prefabricated daycare and school properties offer flexible alternatives for communities for provision of communal services. The paper investigates architectural qualities and financial solutions for rentable and relocatable education facilities in Finland. In particular, the focus is on the communal interests in solving the property management with a portfolio of rentable facilities for different time spans ranging from very short term to periods up to over twenty years. The short term rental terms offer solutions for disaster mitigation such as flooding but also spaces during refurbishment of existing buildings, e.g. due to moisture and mould damage. A core issue is a potential sustainable and flexible co-existence of both permanent and flexible modules that can adapt, for example to demographic changes, improving the efficiency of communal property management. Thus the prefabricated solutions have a potential, if the architectural quality is high enough, to provide alternatives for the real estate strategies of cities also in longer term provision of daycare and school facilities.
\end{abstract}

KEYWORDS: Relocation; Prefabrication; Architecture; Finance; Time

\section{INTRODUCTION}

Several studies have concentrated on the environmental impacts and sustainability related aspects of industrially produced prefabricated buildings. Jaillon et al. (2009) investigated in their study how utilising prefabrication in building construction could help to mitigate the growing problem of building waste generation in Hong Kong area. They found out that the average waste reduction level was about $52 \%$ compared to the conventional on-site construction projects. Bonamente et al. (2014) used Life-cycle assessment (LCA) approach to model carbon and energy foot prints for different size buildings. The results indicate that the main environmental impacts arise from the use phase of the buildings. Similar results were found by Faludi et al. (2012) who studied the life cycle impacts of a $5000 \mathrm{ft}^{2}$ prefabricated commercial building constructed in San Francisco. However, it was also stated that in the case of nearly zero energy buildings manufacturing impacts are the

\footnotetext{
* Corresponding author. E-mail: harry.edelman@tut.fi
}

most dominant. Pons and Wadel (2011) concentrated specifically on environmental impacts of prefabricated school buildings in Catalonia. Using simplified LCA modelling, they compared the $\mathrm{CO}_{2}$ emissions of four technologies; non-prefabricated building technologies as well as prefabricated school facilities made out of wood, steel and concrete. The results show that prefabricated solutions have lower environmental impacts through analysed time period. However, according to the study there is still room for improvement in the processes to further reduce the $\mathrm{CO}_{2}$-emissions and especially the waste generation related to manufacturing and recycling.

Existing body of literature recognises the potentials as well as issues that prefabricated solutions offer in post-disaster environment when rapid response is a necessity. Johnson (2007) describes in her article how post-disaster temporary housing often suffers from high costs, late delivery, poor location and lacking unit design. Bitarafan et al. (2012) evaluated in their study the suitability of the construction methods of cold-formed steel 
structures in reconstructing the areas damaged in natural crises. The comparison was made between on-site construction (stick-built buildings), panelised construction and modular construction. After recognising the important criteria related to the decision-making the Analytic Hierarchy Process (AHP) with 'Complex Proportional Assessment of alternatives with Gray relations' were applied to evaluate these different construction methods. The results indicate that in the case of steel structures, panelised construction is the best way of reconstructing in the damaged areas whereas modular construction is the second best choice before on-site construction.

This paper looks at the resiliency of prefabricated school and pre-school facilities (further on referred as educational facilities) in Finland from the perspective of municipal real estate strategy. In particular, the research looks at the financial success factors and architectural quality in respect of the acceptability of prefabricated solutions. Prefabricated and relocatable wooden modules provide rapid responses to facility needs. However, such elements have faced critique as "barracks". The stakeholders' prejudice against prefabricated solutions as temporary and architecturally weaker solutions has been conventional wisdom on the markets of prefabricated buildings in Finland. This research focuses on owners' and users' interests on prefabricated schools and daycares in six Finnish municipalities. The research targeted answering the question whether prefabricated modules can provide resilient, sustainable, and widely accepted long-term solutions for education facilities of municipalities.

In Finland, moisture and mould damage, and health symptoms caused by them are one of the main reasons for the rapid need of replacing properties. These problems have surfaced especially during the last couple of years. This is mainly a consequence of Moisture and Mould Programme of Ministry of the Environment (Pirinen 2011). The damage cause expenses but an alternative perspective is to consider them also as opportunities for more sustainable ownership of real estate leading to lower lifecycle costs. This article focuses on technological and architectural solutions that could potentially enable a wide acceptance of resilient prefabricated and relocatable solutions with sustainable qualities. The building damage pose an unexpected opportunity for rethinking the communal real estate strategy. Quintessential questions are the opportunities related to the moisture and mould damage leading to more sustainable real estate strategies despite of the investment costs.
However, disaster mitigation is not the only situation when communal real estate strategy can be revised yet rapid responses need to address the entire lifecycle of buildings in order to be sustainable - both in terms of architectural quality and financial sustainability. The aim of the research was to ground a conceptual prefab model for resilient and attractive education facilities to the qualitative data on user-preferences. In the discussion part of this article a model for resilient prefabrication of education facilities is proposed. The model draws from the stakeholder interviews. The nature of the research is qualitative yet mixed methods are used in order to provide prescriptive advice, including financial outlooks, for sustainable development of education facilities, including the redevelopment of disaster prone schools and daycares.

The resiliency of prefabricated facilities is studied in the Finnish context from a temporal perspective including: 1) the needs for rapid responses and sustainability in the long run, 2) user-acceptance and success of prefab solutions in transition towards sustainable real estate strategies, and 3) financial sustainability over time and life-cycle costs. Fast delivery of prefab modules offers solutions for rapid response in sudden decline of operational conditions of buildings such as discovering unacceptable indoor air quality. Businesses based on rental services or standard prefab modules could even deliver facilities directly from manufacturer's stock. The rapid responses should be technically, socially, and financially sustainable in order to be resilient.

Prefabricated modules can be used in two different development strategies of education facilities (Fig. 1). First, the response is intended to be temporary by nature and parallel measures are taken to carry out a longer term solution such as launching a development process of a new school building. In this case, for example, renting temporary re-usable facilities for the users comes in question. These "barrack" solutions are common in Finnish refurbishment projects of schools. Alternatively, providing the user with other premises of a city is an option but suitable facilities are not always available. In the second approach, the rapid response is part of the long-term solution from the day one. The second approach doesn't need to be related to an acute crisis situation. It can be considered as a resilient development strategy for education facilities. But in the case of a crisis situation the rapid response becomes integrated in the long-term facility strategy. Thus the prefab solutions should become "permanent" developments, 


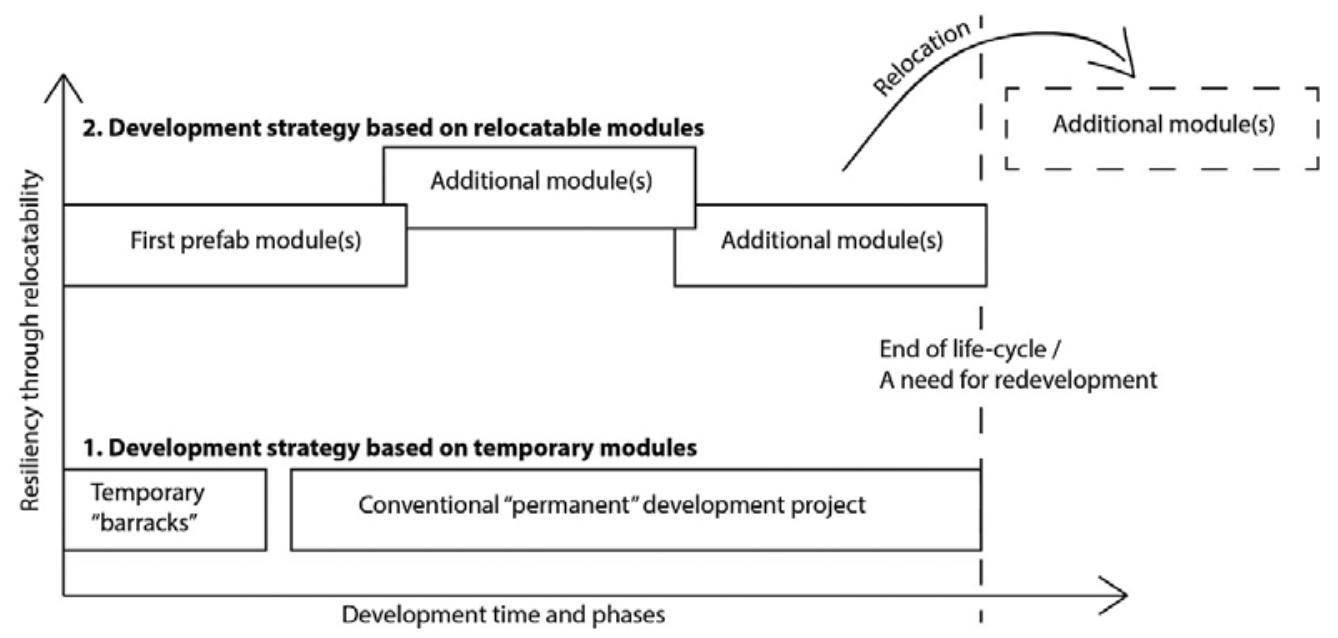

Fig. 1. Development strategies of education facilities from a life-cycle perspective

or, they should be parts of such developments allowing also spatial flexibility through relocatability and ownership arrangements. This research looked at the qualitative and financial conditions enabling the sustainable use of the second development approach increasing the resiliency of education facilities.

\subsection{Related research on the resiliency of education facilities}

The extent of moisture and mould damage have been studied or estimated in scientific studies and national surveys. According to the recent summary (Reijula et al. 2012) of the Finnish studies, it is estimated that the prevalence of significant moisture and mould damage is $12-18 \%$ in schools and kindergartens. The prevalence is even higher, up to $20-26 \%$, in care institutions. The annual repair costs in Finland are $5.6-7.5 \%$ of the annual value of building construction (Reijula et al. 2012).

The moisture and mould related damage are not only restricted to Finland. Smedje et al. (1997), Howden-Chapman et al. (2005), Haas et al. (2007), Holme et al. (2008) have presented similar results from Sweden, New Zealand, Austria, and Norway. In these studies the extent of moisture and mould damage varies between $19 \%$ and $56 \%$. However, the research methods, research materials and even the definitions of moisture and mould damage vary between the studies and therefore the results are not comparable. Altogether, these studies indicate that the moisture and mould damage are a significant issue in multiple countries.

The countermeasures for moisture and mould related damage have been studied in-depth. State- supported remediation projects are the subject of the ongoing HKPro3 (Assessment of state-supported mould remediation projects) follow-up research (2014-2015). The research material consists of approximately 230 projects. The processing of data is unfinished but the preliminary results from 81 projects indicate that in $24(29.6 \%)$ cases the demolition of old building and building a new one is more cost-efficient than the remediation of the old building. The basic operations of these municipal buildings have to continue during the remediation. This and the high prevalence of moisture and mould damage reflect on the constant need for temporary facilities which could also provide longer term solutions on rental basis. Such facilities can offer one potentially sustainable alternative to these remediation projects. This is especially the case if there is uncertainty related to the demographic development of the municipality and thus the need for the educational spaces is uncertain in the future.

\section{METHODOLOGICAL APPROACH}

Mixed methods were used for this research. The qualitative approach allowed finding stakeholders' interests and qualitative issues related to prefab modules. This approach enabled connecting the knowledge of different stakeholders: users of the facilities and the city officials who are responsible for development and real estate management of education facilities. The quantitative financial analysis is connected to the qualitative aspects of education facilities. The methodology aimed at understanding the basis for stakeholders' decisions 
from the perspective of life-cycle design and strategic ownership of property. In particular, the research was designed to answer questions, first, whether the relocatable and rented facilities could deliver the qualitative aspects meeting the stakeholders interests, and second, under what kind of economic conditions such facilities could form a longer term solution for the real estate development instead of using "barracks", for example, in the case of mitigating the moisture and mould related damages if a new development turns out to be more feasible than the renovation of a damaged building.

\subsection{Qualitative approach}

The qualitative research method was based on semi-structured interviews with themes illustrated in Figure 2. All interviews were conducted by the same researcher who emphasised systematically at the beginning of each interview the open nature of the discussion elaborating the themes as helpful but not limiting structure for the discussion. Further, each interviewee was asked for advice if any other person related to the case should be engaged in the discussions.

\section{Themes for stakeholder interviews:}

- general feelings and atmosphere on
relocatable prefab facilities
- image of relocatable facilities
- prior experience on relocatable or
prefabricated facilities
- costs and procurement process
- landscaping of sites
- future needs
- eagerness to invest in additional quality
beyond standard solutions
- temporality in relocatable facilities
- needs for new design, facilities etc.
- repairs and maintenance
- user-perspective and experiences
- suitability of facilities for users' needs

Fig. 2. Interview themes

Selection of cases employed purposive, and not random, sampling methods. The cases form groups, settings and individuals as part of where the processes being studied are most likely to occur (Lincoln, Denzin 1994). The interviewees (see Table 1) were stakeholders related to selected projects delivered by Parmaco Ltd. Parmaco (www.parmaco. fi) manufactures and rents education facilities for municipalities. Parmaco's products were chosen for the analysis of this study because currently in the
Finnish real estate market it is the only producer and renter of relocatable spatial units aiming to meet similar architectural qualities as in more conventional developments. Five case projects were selected out of Parmaco's fleet representing a wide range of age groups for studying the life-cycle aspects. The cases included one of the oldest Parmaco facilities, the daycare of Immola in the City of Helsinki built in 1998. The newest project was Kalevanharju daycare that was under construction during the interviews of the research in 2013.

The actors interviewed can be divided into two categories: Firstly, the actors in charge of the facility's procurement acting as representatives of the public administration. These parties in charge of determining the need for spaces and facilities are responsible for the decision-making and are hence acquainted with the different cities' and communities' building regulations and their specific requirements. Therefore city officials like project planning managers, planning directors, or townscape architects acted as source for gathering data concerned with the clients' perspective.

Secondly, interviews with daily users of the facilities were conducted. Primary school and daycare teachers were interviewed to cover the data concerning the functionality of the facilities in everyday use.

Table 1. Cases and interviewed stakeholders

\begin{tabular}{|c|c|}
\hline \multirow[t]{2}{*}{ City of Turku } & $\begin{array}{l}\text { Townscape architect }(\mathrm{C}) \text {, } \\
\text { Environmental section, } \\
\text { Building control }\end{array}$ \\
\hline & Halikonkatu daycare (S) \\
\hline City of Vantaa & $\begin{array}{l}\text { Project planning manager }(\mathrm{C}) \text {, } \\
\text { Land-use, building and environment }\end{array}$ \\
\hline \multirow[t]{3}{*}{ City of Espoo } & $\begin{array}{l}\text { Planning director }(\mathrm{C}), \text { Premises de- } \\
\text { partment }\end{array}$ \\
\hline & Nipert daycare (S) \\
\hline & Niipperi daycare (S) \\
\hline City of Helsinki & Immola daycare (S) \\
\hline \multirow[t]{2}{*}{ City of Tampere } & $\begin{array}{l}\text { Project planning manager }(\mathrm{C}), \\
\text { Premises department }\end{array}$ \\
\hline & $\begin{array}{l}\text { Kalevanharju daycare, } \\
\text { Visit at the construction site }\end{array}$ \\
\hline $\begin{array}{l}\text { Municipality of } \\
\text { Lempäälä }\end{array}$ & Kulju school (S) \\
\hline
\end{tabular}

(C) = City official, (S) = Staff

The cases were selected having validity and reliability of the data in mind. Validity refers to the extent to which an account accurately represents particular social phenomena (Hammersley 1990). We used the constant comparative method for ensuring the validity of the research (Glaser, Strauss 1967). The selection of interviewees 


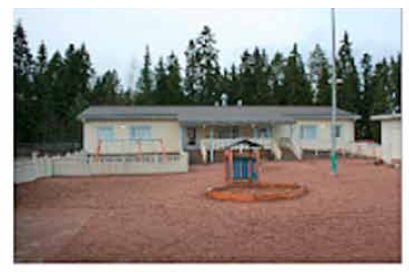

Halikonkatu daycare, Turku

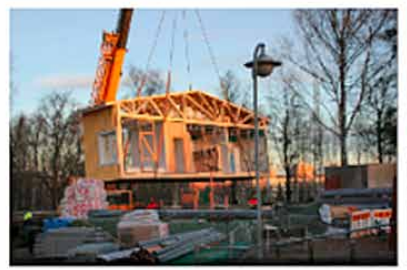

Kalevanharju daycare, Tampere

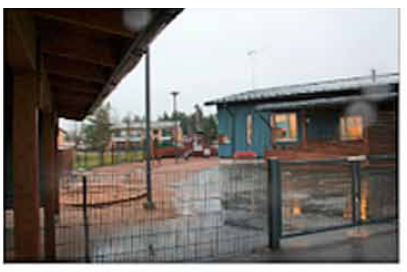

Niperts daycare, Espoo

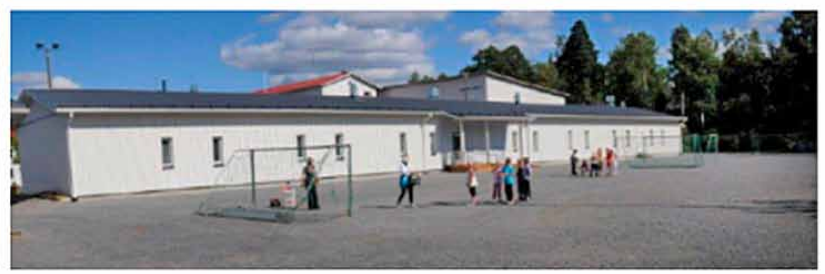

Lempāälā school, Lempāālä

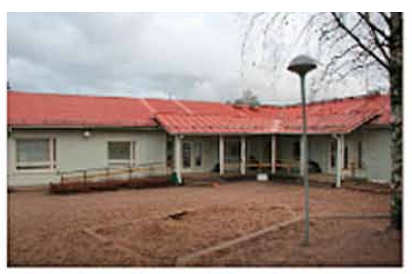

Immola daycare, Helsinki

Fig. 3. Images of the case study locations

having potentially alternatives interests provided a tool for the comparison of data. Reliability refers to the degree of consistency with which instances are assigned to the same category by different observers or by the same observer on different occasions (Hammersley 1992). Choosing multiple developments as case studies was a vehicle to avoid singular opinions related to particular developments. Yet singular observations may have qualitative value for increasing the desirability of the prefabricated developments. The analysis of the data acknowledged the existence of such annotations with particular emphasis that have meaning for the development of prefab facilities.

\subsection{Approach to financial aspects}

From the perspective of an enterprise, it is essential to be able to deliver products that meet the customer's needs and both technical and environmental requirements as cost effectively as possible (Asiedu, Gu 1998; Janz, Westkämper 2007; Niazi et al. 2005). In the same vein, the thinking can be applied to public sector and its services, such as education facilities or even entire residential areas. In both private and public sectors, different investment options should always be thoroughly evaluated because of the limited resources. In the case of Finnish school or daycare properties this is especially true since traditionally those are usually owned by a municipality throughout their whole life cycle. One should be able to consider the impact of lifecycle costs of the buildings rather than the initial investment costs.

In this paper, a highly simplified life cycle cost (LCC) analysis is carried out to compare the economic feasibility of two different alternatives for educational facility investments from the perspective of a municipality. The analysed investment alternatives are not based on real-life counterparts. However, the cost data used in the analysis is gathered from different official sources. The main purpose is to present a potential framework to decision-making related to municipal real estate procurement which relies on the analysis of the life-cycle instead of focusing only to initial investment costs. The LCC-analysis was made between renting a prefabricated school/daycare property, and the traditional alternative, in which a municipality invests to a new property where it acts as an owner.

LCC approach - when carried out fully - identifies all future costs throughout the life cycle of a product and uses discounting techniques to provide an estimation of the present value of those costs. To be able to carry out a thorough LCC-analysis, the following elements should be included (Woodward 1997):

- initial capital costs,

- life of the analysed asset,

- discount rate utilised in the analysis,

- operating and maintenance costs,

- disposal costs,

- information and feedback,

- sensitivity analysis.

In the example calculations, analysis is only carried out to the point of time in which investing to a new property becomes more profitable option. The purpose of the analysis is to define a context for rentable prefabricated modules as an interesting option for the development strategies of municipalities. Only the differing costs between the two alternatives were taken into account. Although some of the elements of LCC listed above have been 
omitted in the study, the possible effect of such elements is still discussed in the following sections.

Choosing the discount rate is one of the most crucial elements in LCC calculations. A high discount rate favours the investments with low initial investment costs and vice versa. Throughout the history of LCC there has been an ongoing conversation about the uncertainty related to the public investments (Arrow, Lind 2014; Lind 2013). As Woodward (1997) states, the estimations regarding the appropriate rate vary from $3 \%$ to over $20 \%$. Because of the low inflation rate of the Finnish operational environment and the risk free nature of the school facility investment we chose to use real discount rate of $4 \%$ in our economic calculations.

\section{CASE DATA AND ANALYSIS}

The interviews resulted ten categories related to the content and qualities of facilities. The categories that emerged from the interviews are shown in Table 2. The categories in relation to the stakeholders were also defined: staff of the facilities and city official responsible for development and management of education facilities. The analysis of data provided the initial categories that was further analysed from the perspectives of stakeholder groups.

\subsection{City officials professional and comparative perspective}

The poor image of prefabricated modules became city officials' key concern. The image was related to the overall reputation of prefabricated modules that are often intended for temporary use. It appeared that the professionals of the construction cluster compared the prefabricated buildings to their experience in developing conventional buildings with a permanent character. It became evident that the buildings with a temporary character were loaded with lower qualitative expectations than the conventional developments. Thus the prefabricated modules were less appreciated in terms of financial and architectural value. In many city offices the prefabricated modules were referred as "placing a hut on a gravel field", "setting up a barrack", or "pavilions" implying to the limited temporal use of the facility.

The conceptions were related to the visual appearance and architecture of the education facilities. The interviews indicated the simple building volumes, facades, materials, entrances, ramps, and canopies giving a less prestigious image to the buildings. In particular, the siting and the landscaping proved to be significant for the conception of image - how well the building is sited and to what extent the surroundings are designed and implemented to fit the building and its functions. However, the city officials considered the landscaping expensive in the case of temporary prefabricated solutions. Also, the prefabricated solutions have not been designed for particular sites in many cases. Thus the connection to the site has received less attention resulting poor quality in urban and landscape design.

The city officials' second concern related to the lack of comprehensive design and building process. The interviewees stated unanimously that offering total services by one responsible service provider would offer a competitive edge. The qualitative problems related to the buildings and sites are

Table 2. Categories of stakeholder interviews

\begin{tabular}{|c|c|c|c|c|c|c|c|c|c|c|}
\hline & $\begin{array}{l}\text { Poor } \\
\text { image }\end{array}$ & $\begin{array}{l}\text { Techni- } \\
\text { cal prob- } \\
\text { lems }\end{array}$ & $\begin{array}{l}\text { Safety } \\
\text { issues }\end{array}$ & $\begin{array}{l}\text { Poorly } \\
\text { function- } \\
\text { ing interi- } \\
\text { ors }\end{array}$ & $\begin{array}{l}\text { Outdoor } \\
\text { spaces } \\
\text { need } \\
\text { improve- } \\
\text { ment }\end{array}$ & $\begin{array}{l}\text { Visual ap- } \\
\text { pearance } \\
\text { needs at- } \\
\text { tention }\end{array}$ & $\begin{array}{l}\text { Functional- } \\
\text { ity of play- } \\
\text { grounds needs } \\
\text { improvement }\end{array}$ & $\begin{array}{l}\text { Need } \\
\text { for total } \\
\text { project } \\
\text { delivery } \\
\text { process }\end{array}$ & $\begin{array}{l}\text { Need } \\
\text { for } \\
\text { open } \\
\text { plans }\end{array}$ & $\begin{array}{l}\text { Additional } \\
\text { building or } \\
\text { equipment, } \\
\text { storages }\end{array}$ \\
\hline & & & & 1 & & & 1 & 1 & & \\
\hline & 1 & & & 1 & & 1 & 1 & 1 & & 1 \\
\hline & & 1 & 1 & 1 & 1 & 1 & & & & \\
\hline & & & 1 & 1 & 1 & & & & & \\
\hline & 1 & & & 1 & & 1 & & 1 & 1 & 1 \\
\hline & & 1 & 1 & 1 & 1 & & 1 & & & \\
\hline & & 1 & & 1 & 1 & & 1 & & & \\
\hline & 1 & & & 1 & & 1 & & 1 & 1 & \\
\hline Total & 3 & 3 & 3 & 8 & 4 & 4 & 4 & 4 & 2 & 2 \\
\hline Officials & 3 & & & 4 & & 3 & 2 & 4 & 2 & 1 \\
\hline Staff & & 3 & 3 & 4 & 4 & 1 & 2 & & & 1 \\
\hline Total & 3 & 3 & 3 & 8 & 4 & 4 & 4 & 4 & 2 & 2 \\
\hline
\end{tabular}


related to the overall procurement and delivery process of the education facilities. One contractor having the responsibilities for building foundations, assembly works, and landscaping would help the project coordination and risk management. However, the same issues could be acknowledged in the procurement process independent from the service providers. The crucial factor is the will for quality and understanding on the final product, that is, the component affecting the quality of prefabricated and relocatable modules.

Third concern that the city officials stated was the flexibility of spatial arrangements. The interviewees emphasised the need for higher occupancy ratio for the educational facilities. This poses a new architectural challenge for the facilities in case those are expected to serve a number of different user groups. The need for sustainable resource-efficiency had clearly surfaced in city administration - how spaces could be shared and used more efficiently. These findings give clear indications for the needs of future research. In the discussion part we elaborate some architectural features improving the adaptability of the prefab modules for different uses.

\subsection{Users' everyday concerns}

Unlike the professional real estate experts, the users of the facilities focused in their opinions on everyday features of the buildings. When the city officials placed the prefabricated modules in the context of conventional development project and related qualitative considerations, the users thought about their personal experiences on the buildings. The division in opinions formed "institutional" and "personal" perspectives on the quality of prefab modules. The institutional perspective plays a significant role in delivering the premises to the user, thus it has an impact on the quality of the premises. Engaging the personal perspectives to the formation of institutional perspective enables the transition to the enhanced quality of prefab modules since the procurement and development processes are managed by the city officials.

The comfort of use, in particular in relation to the indoor air quality and HVAC systems, was the users' only concern. Adaptability to severe weather conditions, in particular to heat during the summer time, became a concern based on individual experiences. Even though the experiences on the uncomfortable indoor climate were short they labelled the overall experience on quality. The same applies to conceptions on the technical spaces as too large rooms, or, sound insulation. However, noise can be a longer lasting issue in education facilities causing problems both in learning and staff's work related well-being.

Safety was the users' second key concern. In particular, the safety of the children and the staff in daily activities had significant importance. Concerns for functional safety included: surface materials, gates, and dangerous spaces such as voids in the foundations. In one of the case study sites, an incident happened during a ball game causing the ball roll under the building - followed by a child fetching the ball. Safety issues received less attention outside staff's actual daily experiences and operational safety. Moisture and mould related safety issues were not a particular concern but "safe and healthy" and "modular, healthy and safe" indicated the importance of safety. In fact, safety was also considered as the most important feature for users in temporary prefabricated buildings. This indicates a willingness to downgrade the qualitative aspects of prefabricated modules without seeing a longer term value for the buildings. However, the modules can have a role in increasing the sustainability of facility strategy with enhanced qualitative features. The prefabricated modules play certainly an important role for children using the spaces potentially for several years.

Outdoor spaces became the third concern of the users who were concerned about the general appearance of the yards. In particular, when a temporary facility is placed in location without any landscaping, such as gravel fields, the qualitative problems arise. The lack of vegetation has also functional effects while many case study sites lacked trees shading the buildings and the playgrounds. Different playground facilities were also considered important as well as sheds and storage spaces. The functional and affordable landscape elements, innovative use of rainwater harvesting, or landfills, could form locations that are attractive to children and encourage playing. The temporary character of facilities had decreased the qualities of outdoor spaces in all case study locations.

\subsection{Shared constructs of architectural quality}

The responses to the architectural quality divided equally among the users and city officials. Both groups were concerned about the interior design yet in a different fashion. The city officials called 
for more flexible use of space in general while the users' views were more focused. They found a lack of user participation in design. In particular, they were critical about the pedagogical spaces that fall a short of the state-of-the-art education facilities. The small size and locations of administrative rooms got also critique as well as the details such as too small storage spaces. Users found the mixed use spaces useful, for example, a combined room that can be used both for the children's activities and the parents' meetings.

Unexpectedly, the exterior architecture was merely city officials' concern. They had a clear professional view on the architecture while comparing it to the permanent education facilities, or other architectural features, such as using exterior materials like metal rarely used in Finnish education facilities. Remarks such as "the architectural quality doesn't seem convincing", or, "lack of uplifting architecture" indicated a reserved attitude towards the current solutions of prefabricated education facilities. The city officials sought features beyond standard solutions labelling some particularity to the education facilities of distinct city. The notion resurfaced in the aspirations of having an own "catalogue collection" of prefabricated education facilities for the city. The users in turn called for more simple ideas for upgrading the architecture through colouring. Additionally, they focused from the users' point of view to the details such as handrails and stairs and their functionality.

The users and the city officials discussed the functionality of the outdoor spaces from different perspectives. In general, the city officials had less actual experience on the use of outdoor spaces. The city officials' views focused more on the exterior architecture such as using the canopies, ramps, and stairs as harmonic parts of the facades creating more consistent architecture. The users paid attention to the lack of outdoor storages and greening of the yard which would provide shading during the hot summer days. This is an important feature both in terms of comfort and health while avoiding exposing children to the direct sunlight. In general, the design and implementation of outdoor spaces is neglected in relocatable education facilities even though it has great functional and architectural meaning.

\subsection{Economic feasibility of the prefabricated daycare and school modules}

Simplified LCC-analysis was carried out to study the municipal economic feasibility of the prefabricated school and daycare modules. The comparison was made between two imaginary investment alternatives: one, where municipality invests to permanent solution and other, where facility is provided by renting relocatable modular elements. The main objective was to find out the context (if there is one) in which it would be cost effective to rent educational facilities instead of investing to a permanent solution built using conventional construction methods.

The calculation variables used as well as their sources are presented in Table 3. Only the costs differing between the two investment alternatives were taken into account. In Finland, buildings are almost always constructed according to the part D3 of the National Building Code (Ministry of the Environment 2011) which defines the minimum requirements considering the energy efficiency of new buildings. This leads to the fact that the specific heating energy consumption $\left(\mathrm{kWh} / \mathrm{m}^{2}\right)$ can be assumed to be similar between the two studied alternatives. The predominant position of the

Table 3. The variables used in the LCC-analysis when comparing the two investment alternatives to arrange education spaces required from the perspective of a municipality

\begin{tabular}{|c|c|c|c|c|c|}
\hline \multicolumn{3}{|c|}{ Municipality invests to a new educational property } & \multicolumn{3}{|c|}{ Municipality rents the spaces required } \\
\hline Variable & Value & Source & Variable & Value & Source \\
\hline Amount of pupils & $350 / 250$ & - & Amount of pupils & $350 / 250$ & - \\
\hline Floor area required & $15 \mathrm{~m}^{2} /$ pupil & $\begin{array}{l}\text { Finnish National } \\
\text { Board of Education } \\
2012\end{array}$ & $\begin{array}{l}\text { Floor area re- } \\
\text { quired }\end{array}$ & $\begin{array}{l}15 \mathrm{~m}^{2} / \\
\text { pupil }\end{array}$ & $\begin{array}{l}\text { Finnish National } \\
\text { Board of Education } \\
2012\end{array}$ \\
\hline Investment cost & $2433 € / \mathrm{m}^{2}$ & $\begin{array}{l}\text { Haahtela and Kiiras } \\
2014\end{array}$ & Monthly rent & $17 € / \mathrm{m}^{2}$ & Parmaco Ltd. 2014 \\
\hline $\begin{array}{l}\text { The cost of mainte- } \\
\text { nance }\end{array}$ & $8.2 € / \mathrm{m}^{2}$ & Lonka et al. 2012 & $\begin{array}{l}\text { Annual increase } \\
\text { of the rent }\end{array}$ & $3 \%$ & Parmaco Ltd. 2014 \\
\hline $\begin{array}{l}\text { The cost of technical } \\
\text { deterioration }\end{array}$ & $\begin{array}{l}2 \% \text { of the invest- } \\
\text { ment cost per year }\end{array}$ & Nippala et al. 2006 & & & \\
\hline
\end{tabular}


district heating ${ }^{1}$ in the Finnish building stock the utility costs in the both alternatives are very similar and thus can be omitted from the analysis. Land value can be omitted from the analysis based on the fact that comparison is made between to investment alternatives for the same location. In both cases the area of space required is expected to be the same $15 \mathrm{~m}^{2} /$ pupil. The main differences between the investment alternatives are the large initial capital cost and the cost of maintenance and technical deterioration included in the alternative where municipality invests to a new education facility. The costs of maintenance as well as the cost of deterioration are included in the monthly rent in the second alternative.

Residual value of the investment was ignored in these calculations. This is because if municipality uses the renting model to acquire spaces it does not actually own the facility. In the case of building a new facility the residual value is really hard to define. Technical value based on the age of the building can be quantified using various methods but the specific character of the education facilities makes this problematic. Usually large school facilities are not appealing from the perspective of real estate investors. This is mainly due to the fact that it requires significant amount of alterations to modify the spaces to support other activities. Residual value can even thought to be negative if demolition and waste management costs of the building are considered.

Two calculation scenarios were created for the comparison of the investment alternatives. In the first one the amount of pupils was assumed to stay constant and in the second there was a decrease in the number of students 10 years after the initial investment. The decreasing scenario was included in the study because in Finland there are many shrinking cities having a declining number of pupils. Additionally, in different urban scales this phenomenon may apply to growth centres also some school districts gain pupils while others have fewer of them in the upcoming years. Costs were assumed to be the same in both scenarios. This kind of sensitivity analysis was performed to investigate financial resiliency. In other words, the amount of prefabricated modules can be decreased or increased at any phase of the life cycle based on the demand affecting the cost effectiveness of the studied investment alternatives. The results of these scenarios are presented in Figures 4 and 5.

\footnotetext{
${ }^{1}$ When measured in floor area $75 \%$ of the educational facilities in Finland are using district heating as a source for their heating energy (Official Statistics of Finland 2014)
}

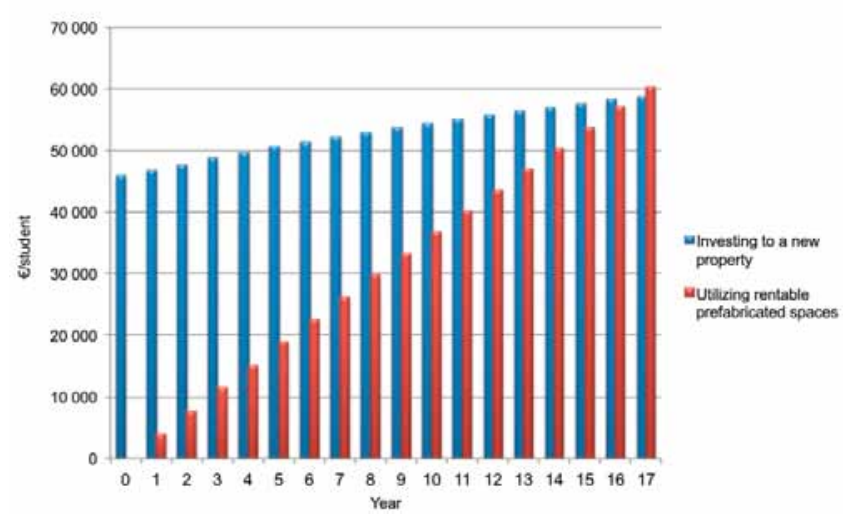

Fig. 4. The cumulative discounted cots of the two investment alternatives when the amount of students is assumed to stay constant (350 pupils) through the years

If the amount of pupils is assumed to stay in 350 throughout the life cycle of the school property and a real discount rate of $4 \%$ is used in the analysis, it appears that renting the spaces becomes a more expensive alternative after 17 years. There are no costs of renting in the first year of studied time period. That is because it is assumed that building a new school property takes approximately one year. Prefabricated elements can be brought to the site in a matter of weeks and the renting costs start after the building phase of the first investment alternative is finished. Taking into consideration the simplified character of the calculations one would be safe to assume that the break-even point is situated somewhere between 15 and 20 years.

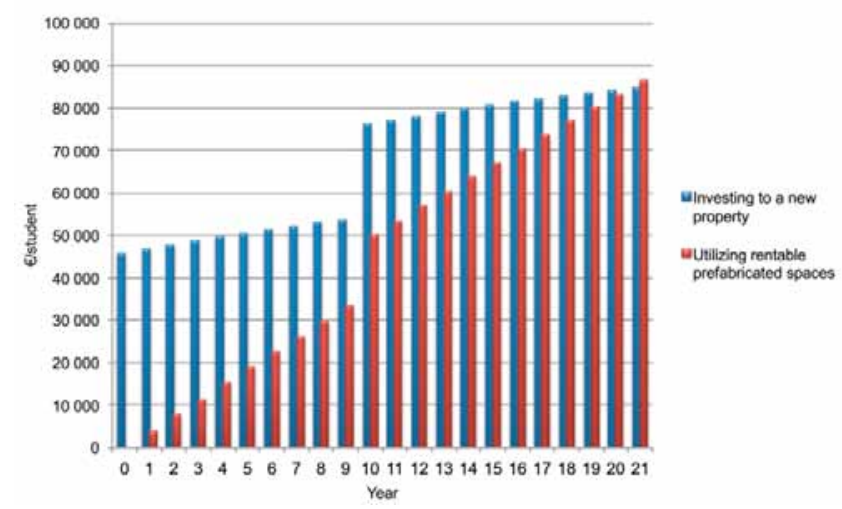

Fig. 5. The cumulative discounted cots of the two investment alternatives when there is a decrease of 100 pupils (from 350 to 250) ten years after the initial investment

One benefit of the rentable prefab modules is the fact that the system is spatially very flexible and responses well to different requirements. The calculation scenario presented in Figure 5 describes this phenomenon. In this scenario an as- 
sumption is made that after ten years the amount of students has declined from 250 to 350 . If a municipality has originally chosen to build new school property it is very hard to find compensatory use to empty spaces without large scale alterations. However, in the case of prefabricated modules the spaces no longer required can be moved to another location and the rental agreement can be adjusted to concern only the modules remaining. If the amount of students declines from 250 to 350 the results of the economic calculation becomes more favourable towards rentable spaces. According to the calculations, building and owning a school facility becomes more profitable after 21 years.

The simplistic economic calculations presented above were made to provide information regarding the economic decision-making framework of a municipality when making a choice between renting and owning educational facilities. In the Finnish operational environment the permanent building and ownership solution is usually favoured over renting. According to the results, it seems that especially in municipalities facing an uncertain future the model of renting the spaces required should be seriously considered. Furthermore, regarding the prefabricated modules there may be some significant economic and environmental benefits gained at the end of the life-cycle regarding the demolition costs and waste management. Modules can be renovated and relocated to a new location when no longer needed in the current location.

It should be noted that usually municipalities make their property investments using long writeoff periods and with loan programs that have small financing costs. If this fact would have been taken into account in the calculations, the results might be more favourable towards the alternative where a municipality builds the facilities.

\section{DISCUSSION}

In a number of cases, the moisture and mould damage force the municipalities to consider the redevelopment strategies. In this paper the qualitative and architectural prerequisites for wider acceptance of prefabricated education facilities and the financial feasibility of such solutions from the perspective of LCC were studied.

Previous studies have shown that the same level of design quality has not been applied to the prefabricated education facilities than on the housing markets (Newton 2009). On the other hand, the relevance of quality has been identified in fourteen studies during the years 1994-2000 showing a correlation between learning outcomes and physical conditions (Lyons 2001). A more recent study looking at seven UK based school facilities claims a $25 \%$ impact on the learning outcomes based on physical setting (Barrett et al. 2013). In terms of design principles, the concept labelled as Individualisation is prominent with design parameters such as Choice (quality furniture and fixture), Flexibility (spatial configurations), and Connection (wide and orientable corridors) (Barrett et al. 2013).

This study supports the above findings. However, earlier research has paid mainly attention on the interiors of the education buildings. Interiors were also a concern in this research while exterior spaces caught attention from the perspectives of functionality, comfort, aesthetics, and safety. The Finnish tradition of children playing a lot outdoors, independent from the season or weather, may have had an impact on the users' appreciation of the quality of the exterior spaces and architecture. The city officials making the procurement and development decisions paid a lot of attention to the exterior architecture and how buildings fit to the site.

The case studies showed that the exterior architecture plays a key role in choosing the development strategies. Conceptions on insufficient architectural quality and poor siting of relocatable and prefabricated solutions drop the industrially manufactured solutions quickly out of the development process. However, affordable design solutions such as greenery, hillocks, outdoor furniture, siting the building properly, entrance areas, and the placing and sizing of windows can significantly improve both the appeal and functionality of the conventional Finnish prefabricated education facilities. With such improvements the prefabricated solutions can provide a sustainable alternative to permanent developments also from the perspective of LCC depending on the expected time-of-use of the buildings in a particular location.

The qualitative finds resulting the ten categories on architectural aspects are valid in the context of selected cases as samples on conventional Finnish development of prefabricated education facilities. Further research would be needed to investigate the qualitative conceptions in other countries, for example, the use of outdoor spaces may differ based on the culture of children playing outdoors. Urban contexts, on the other hand, can be expected to be similar in Western societies including both shrinking and growing cities. Thus the economical hypothesis could well be valid, for example, in several European countries while applying local input values for lifecycle costs. 
From the perspective of the LCC-analysis carried out, it seems that rentable prefabricated solutions are especially suitable for the municipalities that are facing an uncertain future and thus having trouble in predicting future need for education facilities. The calculation results imply that changes in the demand of space improve the economic feasibility of prefabricated modules. Because of the sustainable and resilient nature of the prefabricated spaces, a proper cost benefit analysis could be a more suitable method for comparison. The calculations presented in this paper should not be taken as an absolute fact regarding the decision-making of municipal facility management. The simplified analysis was made to provide an outlook of the situational economic benefits of rentable prefabricated modules. Further analysis is required to obtain more generic information about the full effects of the investment alternatives presented in this paper.

\section{CONCLUSIONS}

Five cases were used for studying the qualitative features of prefabricated education facilities. The cases consisted of site visits and stakeholder interviews including users of the facilities and city officials responsible for the development and management of the facilities. Additionally, the LCCs were studied from a prescriptive perspective in order to provide information for the communal decision-making process related to redevelopment and repair decisions in particular on moisture and mould damaged education facilities.

The findings of the study indicate that the prefabricated education facilities can provide an alternative for municipal development strategy on the education facilities. The existing qualitative shortcomings on the markets of Finnish prefabricated education facilities can be fixed to reach the architectural features associated with the conventional developments. The crisis related to moisture and mould damage can provide an opportunity for restructuring the real estate strategy on education facilities. This opportunity may help to mitigate the financial burden through the decrease of lifecycle costs if the permanent developments will be replaced by flexible re-locatable and prefabricated modules. The number of facilities worth demolishing instead of refurbishing can become greater. The consideration needs to take into account the individual circumstances such as the demographic structure of the municipality, the potential location on shrinking regions, or the overall LCC.
The research indicated that the use of prefabricated and relocatable modules with high architectural quality calls for integrated development process. Such approach takes a comprehensive responsibility for the siting and landscaping of the development. Otherwise it is likely that the crucial qualitative components, such as foundations and greenery, become neglected while the responsibility for the end product is vague in the development process. The city officials as customers also called for single responsible party for the entire process of construction. Thus the manufacturing and marketing of prefabricated solutions should be developed to more comprehensive service models covering the entire value chain.

\section{REFERENCES}

Arrow, K. J.; Lind, R. C. 2014. Uncertainty and the evaluation of public investment decisions, Journal of Natural Resources Policy Research 6(1): 29-44. http://dx.doi.org/10.1080/19390459.2014.867640

Asiedu, Y.; Gu, P. 1998. Product life cycle cost analysis: state of the art review, International Journal of Production Research 36(4): 883-908.

http://dx.doi.org/10.1080/002075498193444

Barrett, P.; Zhang, Y.; Moffat, J.; Kobbacy, K. 2013. A holistic, multi-level analysis identifying the impact of classroom design on pupils' learning, Building and Environment 59: 678-689.

http://dx.doi.org/10.1016/j.buildenv.2012.09.016

Bitarafan, M.; Hashemkhani Zolfani, S.; Arefi, S. L.; Zavadskas, E. K. 2012. Evaluating the construction methods of cold-formed steel structures in reconstructing the areas damaged in natural crises, using the methods AHP and COPRAS-G, Archives of Civil and Mechanical Engineering 12: 360-367. http://dx.doi.org/10.1016/j.acme.2012.06.015

Bonamente, E.; Merico, M. C.; Rinaldi, S.; Pignatta, G.; Pisello, A. L.; Cotana, F.; Nicolini, A. 2014. Environmental impact of industrial prefabricated buildings: carbon and energy footprint analysis based on an LCA approach, Energy Procedia 61: 2841-2844. http://dx.doi.org/10.1016/j.egypro.2014.12.319

Faludi, J.; Lepech, M. D.; Loisos, G. 2012. Using life cycle assessment methods to guide architectural decision-making for sustainable prefabricated modular buildings, Journal of Green Building 7(3): 151-170. http://dx.doi.org/10.3992/jgb.7.3.151

Finnish Ministry of the Environment. 2011. D3 Energy Management in Buildings, Regulations and Guidelines 2012 [online]. Helsinki: Department of the Built Environment. Available at: http://www.finlex.fi/data/ normit/37188-D3-2012_Suomi.pdf [accessed February 2015] (In Finnish)

Finnish National Board of Education. 2012. Perusja esiopetuksen tilantarpeen tunnuluvut [Characteristics of space requirements in educational facilities] [online]. Helsinki. Available at: http://www.oph.fi/down- 
load/139700_esi_ja_perusopetuksen_tunnusluvut.pdf [accessed February 2015] (In Finnish)

Glaser, B. G.; Strauss, A. L. 1967. The discovery of grounded theory: strategies for qualitative research. Chicago: Aldine Pub. Co.

Haahtela, Y.; Kiiras, J. 2014. Talonrakennuksen kustannustieto 2014 [The costs of construction 2014]. Helsinki: Haahtela-kehitys Ltd. (In Finnish)

Haas, D.; Habib, J.; Galler, H.; Buzina, W.; Schlacher, R.; Marth, E.; Reinthaler, F. F. 2007. Assessment of indoor air in Austrian apartments with and without visible mold growth, Atmospheric Environment 41: 5192-5201.

http://dx.doi.org/10.1016/j.atmosenv.2006.07.062

Hammersley, M. 1990. Reading ethnographic research: a critical guide. Longman.

Hammersley, M. 1992. By what criteria should ethnographic research be judged?, in What's wrong with ethnography? Oxon: Routledge, 57-82.

Holme, J.; Geving, S.; Jenssen, J. A. 2008. Moisture and mould damage in Norwegian houses, in Proceedings of the $8^{\text {th }}$ symposium on Building Physics in the Nordic Countries, 16-18 June 2008, Copenhagen, Denmark.

Howden-Chapman, P.; Saville-Smith, K.; Crane, J.; Wilson, N. 2005. Risk factors for mold in housing: a national survey, Indoor Air 15: 469-476. http://dx.doi. org/10.1111/j.1600-0668.2005.00389.x

Jaillon, L.; Poon, C. S.; Chiang, Y. H. 2009. Quantifying the waste reduction potential of using prefabrication in building construction in Hong Kong, Waste Management 29(1): 309-320.

http://dx.doi.org/10.1016/j.wasman.2008.02.015

Janz, D.; Westkämper, E. 2007. Design to life cycle by value-oriented life cycle costing, in Advances in Life Cycle Engineering for Sustainable Manufacturing Businesses. London: Springer, 461-466. http://dx.doi.org/10.1007/978-1-84628-935-4_80

Johnson, C. 2007. Strategic planning for post-disaster mitigation, Disasters 31(4): 435-458. http://dx.doi.org/10.1111/j.1467-7717.2007.01018.x

Lincoln, Y. S.; Denzin, N. K. 1994. The fifth moment, in Denzin, N.; Lincoln, Y. (Eds.). Handbook of Qualitative Research. Thousand Oaks, CA: Sage, 575-586.

Lind, R. C. 2013. The rate of discount and the application of social benefit - cost analysis in the context of energy policy decisions, in Lind, R. C. et al. (Eds.). Discounting for time and risk in energy policy. Washington DC: Resources for the Future Inc., 443-457.

Lonka, H.; Lallukka, V.; Romppainen, S. 2012. ItäUudenmaan kunta palveluverkkoselvitys - Kuntien toimitilaverkoston ja siinä tapahtuvan toiminnan selvitys [Assessment of the service network in Eastern Uusimaa Area in Finland] [online]. Helsinki: Gran- lund Ltd. Available at: http://www.sipoo.fi/easydata/ customers/sipoo/files/2011_hallinto/iu-selvitys/loppuraportit/iuk_palveluverkkoselvitys_2014-6-9.pdf [accessed February 2015]

Lyons, J. B. 2001. Do school facilities really impact a child's education? IssueTrak: A CEFPI Brief on Educational Facility Issues. Council of Educational Facility Planners, International, Scottsdale, AZ.

Newton, C. 2009. Learning through prefabrication, undisciplined!, in Proceedings of the Design Research Society Conference 2008, 16-19 July 2008, Sheffield Hallam University, Sheffield, UK, 283-295.

Niazi, A.; Dai, J. S.; Balabani, S.; Seneviratne, L. 2005. Product cost estimation: technique classification and methodology review, Journal of Manufacturing Science and Engineering 128(2): 563-575.

http://dx.doi.org/10.1115/1.2137750

Nippala, E.; Vainio, T.; Nuuttila, H. 2006. Rakennustyyppikohtainen peruskorjaustarpeen arviointi kuntien rakennuksissa [Assessment of renovation needs in municipal buildings]. Helsinki: The membership of the Association of Finnish Local and Regional Authorities. (In Finnish)

Official Statistics of Finland. 2014. Buildings and freetime residences [online]. Helsinki: Statistics Finland. Available at: http://pxnet2.stat.fi/PXWeb/pxweb/en/ StatFin/StatFin_asu_rakke/020_rakke_tau_102. px/?rxid=c9b68d3d-bc31-4861-bcb7-0c601262815d

Parmaco Ltd. 2014. Cost estimates based on personal correspondence between the company (Parmaco Ltd.) and the author in December 2014.

Pirinen, J. 2011. Buildings inspections in Finland fighting against moulds, in Vinha, J.; Piironen, J.; Salminen, K. (Eds.). Proceedings of the $9^{\text {th }}$ Nordic Symposium on Building Physics, 29 May-2 June 2011, Tampere, Finland, 31-43.

Pons, O.; Wadel, G. 2011. Environmental impacts of prefabricated school buildings in Catalonia, Habitat International 35: 553-563. http://dx.doi.org/10.1016/j.habitatint.2011.03.005

Reijula, K.; Ahonen, G.; Alenius, H.; Holopainen, R.; Lappalainen, S.; Palomäki, E.; Reiman, M. 2012. Rakennusten kosteus- ja homeongelmat [Damp and Mould Damage in Finnish Building Stock]. Eduskunnan tarkastusvaliokunnan julkaisu 1/2012. (Summary in English)

Smedje, G.; Norbäck, D.; Edling, C. 1997. Subjective indoor air quality in schools in relation to exposure, Indoor Air 7(2): 143-150. http://dx.doi.org/10.1111/j.1600-0668.1997.00009.x

Woodward, D. G. 1997. Life cycle costing - theory, information acquisition and application, International Journal of Project Management 15(6): 335-344. http://dx.doi.org/10.1016/S0263-7863(96)00089-0 